\title{
Anterior Clinoid Metastasis Removed Extradurally: First Case Report
}

\author{
Mirza Pojskić ${ }^{1}$ Blazej Zbytek ${ }^{2,3} \quad$ Kenan I. Arnautovićc ${ }^{4,5}$
}

${ }^{1}$ Department of Neurosurgery, Philipps University of Marburg, Marburg, Germany

2 Department of Pathology and Laboratory Medicine, Center for Adult

Address for correspondence Kenan I. Arnautović, MD, PhD, Semmes Murphey Neurologic \& Spine Institute, 6325 Humphreys Blvd., Memphis, TN 38120, United States (e-mail: kenanarnaut@yahoo.com).

Memphis, Tennessee, United States

3 Pathology Group of the MidSouth, Memphis, Tennessee,

United States

${ }^{4}$ Semmes Murphey Neurologic \& Spine Institute, Memphis,

Tennessee, United States

${ }^{5}$ Department of Neurosurgery, University of Tennessee Health

Science Center, Memphis, Tennessee, United States

J Neurol Surg Rep 2018;79:e55-e62.

\begin{abstract}
Background We report a case of isolated metastasis on the anterior clinoid process (ACP) mimicking meningioma.

Clinical Presentation A 58-year-old male presented with headaches, right-sided visual disturbances, and blurred and double vision. The cause of double vision was partial weakness of the right III nerve, resulting from compression of the nerve by "hypertrophied" tumor-involved right anterior clinoid. Medical history revealed two primary malignant tumors-male breast cancer and prostate cancer (diagnosed 6 and 18 months prior, respectively). The patient was treated with chemotherapy and showed no signs of active disease, recurrence, or metastasis. Postcontrast head magnetic resonance imaging (MRI) showed extra-axial well-bordered enhancing

Keywords

- anterior clinoid process

- extradural clinoidectomy

- metastasis

- anterior clinoid metastasis

- case report mass measuring $1.6 \times 1.1 \times 1 \times 1 \mathrm{~cm}$ (anteroposterior, transverse, and craniocaudal dimensions) on the ACP, resembling a clinoidal meningioma. Extradural clinoidectomy with tumor resection was performed via right orbitozygomatic pretemporal skull base approach. Visual symptoms improved. Follow-up MRI showed no signs of tumor residual or recurrence.

Conclusion This is the first case report of a metastasis of any kind on ACP. Metastasis should be included as a part of the differential diagnosis of lesions of the anterior clinoid. Extradural clinoidectomy is a safe and effective method in the treatment of these tumors.
\end{abstract}

\section{Background and Importance}

We report a first case of isolated metastasis on the anterior clinoid process (ACP) mimicking a meningioma, which should be added to the differential diagnosis of the processes of ACP. The most common lesions of the anterior clinoid

received

September 6, 2017 accepted after revision April 10, 2018
DOI https://doi.org/

10.1055/s-0038-1655773. ISSN 2193-6358. process are meningiomas. ${ }^{1,2}$ There are 11 different pathological entities described so far on the ACP other than meningioma ( - Table $\mathbf{1}){ }^{3-33}$

Clinoidectomy is the key element of the surgical treatment of neoplastic lesions of the ACP. It was developed initially as an intradural technique for approach to internal (c) 2018 Georg Thieme Verlag KG Stuttgart . New York
License terms

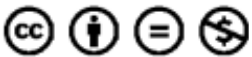


Table 1 Nonmeningioma pathology of the anterior clinoid process

\begin{tabular}{|c|c|c|c|}
\hline $\begin{array}{l}\text { Nonmeningioma } \\
\text { pathology of } \\
\text { the ACP }\end{array}$ & Author and year & Symptoms & Treatment and outcome \\
\hline \multirow[t]{21}{*}{$\begin{array}{l}\text { Mucocele } \\
21 \text { cases }\end{array}$} & Nundkumar et al, $2012^{24}$ & Sudden painless loss of vision & $\begin{array}{l}\text { Endoscopic transnasal approach, } \\
\text { complete recovery }\end{array}$ \\
\hline & Johnson et al, $1986^{18}$ & $\begin{array}{l}\text { Retrobulbar pain with loss of } \\
\text { vision }\end{array}$ & $\begin{array}{l}\text { Pterional approach; incomplete } \\
\text { recovery }\end{array}$ \\
\hline & Schwaighofer et al, $1989^{27}$ & $\begin{array}{l}\text { Retro-orbital pain with loss of } \\
\text { vision }\end{array}$ & $\begin{array}{l}\text { Frontal craniotomy, complete } \\
\text { recovery }\end{array}$ \\
\hline & Dunya et al, $1996^{11}$ & Double vision & $\begin{array}{l}\text { Endoscopic transsphenoidal, } \\
\text { subjective improvement }\end{array}$ \\
\hline & Garaventa et al, $1997^{13}$ & $\begin{array}{l}\text { Retro-orbital pain with loss of } \\
\text { vision }\end{array}$ & $\begin{array}{l}\text { Endoscopic transnasal, complete } \\
\text { recovery }\end{array}$ \\
\hline & Chou et al, $1999^{8}$ & Progressive loss of vision & $\begin{array}{l}\text { Supraorbital craniotomy, com- } \\
\text { plete recovery }\end{array}$ \\
\hline & Chung et al, $1999^{9}$ & Headache, diplopia & $\begin{array}{l}\text { Pterional approach, slight } \\
\text { recovery with light } \\
\text { perception }\end{array}$ \\
\hline & Lim et al, $1999^{21}$ & Diplopia, III nerve palsy & $\begin{array}{l}\text { Frontotemporal orbitozygo- } \\
\text { matic approach, recovery of III } \\
\text { nerve palsy }\end{array}$ \\
\hline & Hejazi et al, $2001^{14}$ & Ophthalmoplegia, visual loss & Transnasal, complete recovery \\
\hline & Righini et al, $2006^{26}$ & Monocular blindness & Endoscopic, complete recovery \\
\hline & $\begin{array}{l}\text { Deshmukh and DeMonte, } \\
2007^{10}\end{array}$ & Blind spot & $\begin{array}{l}\text { Conservative treatment with oral } \\
\text { antibiotics for sinusitis, complete } \\
\text { recovery }\end{array}$ \\
\hline & Thurtell et al, $2007^{28}$ & Painful visual loss & Pterional approach, no recovery \\
\hline & Vaphiades et al, $2007^{31}$ & Painless visual loss & $\begin{array}{l}\text { Endoscopic transnasal, slight } \\
\text { recovery }\end{array}$ \\
\hline & Kwon et al, $2009^{20}$ & Sudden onset of blurry vision & Transnasal, slight recovery \\
\hline & Arnavielle et al, $2010^{4}$ & Painful optic neuropathy & Endoscopic, complete recovery \\
\hline & Chagla et al, $2010^{5}$ & Headache, visual loss & $\begin{array}{l}\text { Supraorbital craniotomy, slight } \\
\text { recovery }\end{array}$ \\
\hline & Forer et al, $2010^{12}$ & $\begin{array}{l}\text { Unilateral ophthalmoplegia, eye } \\
\text { redness }\end{array}$ & $\begin{array}{l}\text { Image-guided endoscopic, com- } \\
\text { plete recovery }\end{array}$ \\
\hline & Moisseiev et al, $2013^{23}$ & Visual loss & Surgery, not specified \\
\hline & Wang et al, $2013^{32}$ & $\begin{array}{l}\text { Retro-orbital pain, double vision, } \\
\text { III, IV, VI nerve palsy }\end{array}$ & $\begin{array}{l}\text { Pterional approach, incomplete } \\
\text { recovery }\end{array}$ \\
\hline & Aoyama et al, $2014^{3}$ & Headache, visual loss & $\begin{array}{l}\text { Craniotomy (not specified), } \\
\text { slight improvement }\end{array}$ \\
\hline & Hopf-Jensen et al, $2014^{17}$ & III nerve palsy, diplopia & $\begin{array}{l}\text { Pterional approach, intradural } \\
\text { clinoidectomy, complete } \\
\text { recovery }\end{array}$ \\
\hline \multirow{2}{*}{$\begin{array}{l}\text { Cavernous } \\
\text { hemangioma } \\
2 \text { cases }\end{array}$} & Mansour et al, $2017^{22}$ & Incidental finding & $\begin{array}{l}\text { Pterional approach, no } \\
\text { complications }\end{array}$ \\
\hline & Yamashita et al, $2006^{33}$ & Headache, visual impairment & $\begin{array}{l}\text { Pterional approach, complete } \\
\text { recovery }\end{array}$ \\
\hline $\begin{array}{l}\text { Isolated fibrous } \\
\text { dysplasia of the } \\
\text { ACP } \\
1 \text { case }\end{array}$ & Chang, $2009^{6}$ & One-sided blindness & $\begin{array}{l}\text { Extradural clinoidectomy } \\
\text { via pterional approach } \\
\text { in “no drill” technique, no } \\
\text { recovery }\end{array}$ \\
\hline $\begin{array}{l}\text { Pilocytic } \\
\text { astrocytoma } \\
1 \text { case }\end{array}$ & Hong et al, $2014^{16}$ & One-sided visual loss & $\begin{array}{l}\text { Frontotemporal craniotomy, } \\
\text { improved vision }\end{array}$ \\
\hline
\end{tabular}


Table 1 (Continued)

\begin{tabular}{|c|c|c|c|}
\hline $\begin{array}{l}\text { Nonmeningioma } \\
\text { pathology of } \\
\text { the ACP }\end{array}$ & Author and year & Symptoms & Treatment and outcome \\
\hline $\begin{array}{l}\text { Inflammatory } \\
\text { pseudotumor } \\
1 \text { case }\end{array}$ & Kasliwal et al, $2008^{19}$ & Visual diminution and proptosis & $\begin{array}{l}\text { Surgical decompression, high- } \\
\text { dose steroids, complete recovery }\end{array}$ \\
\hline $\begin{array}{l}\text { Pyocele } \\
1 \text { case }\end{array}$ & O'Donnell et al, $2013^{25}$ & $\begin{array}{l}\text { Fever, decreased vision, III and VI } \\
\text { nerve palsy }\end{array}$ & $\begin{array}{l}\text { Intravenous antibiotics followed } \\
\text { by surgery, approach not speci- } \\
\text { fied, complete recovery }\end{array}$ \\
\hline $\begin{array}{l}\text { Dermoid cyst } \\
1 \text { case }\end{array}$ & Higgins and Schimdt, $1996^{15}$ & Not specified & $\begin{array}{l}\text { Stereotactic biopsy followed by } \\
\text { craniotomy and resection, not } \\
\text { specified }\end{array}$ \\
\hline $\begin{array}{l}\text { Necrotizing } \\
\text { sarcoid } \\
\text { granuloma } \\
1 \text { case }\end{array}$ & Tobias et al, $2003^{29}$ & $\begin{array}{l}\text { Left visual deterioration and } \\
\text { proptosis }\end{array}$ & $\begin{array}{l}\text { Frontotemporal craniotomy with } \\
\text { extradural removal of the ACP; } \\
\text { corticosteroid therapy, visual } \\
\text { improvement, stable disease }\end{array}$ \\
\hline $\begin{array}{l}\text { Bony protuber- } \\
\text { ance of the ACP } \\
\text { leading to } \\
\text { aneurysm of the } \\
\text { ICA due to trauma }\end{array}$ & Cheong et al, $2011^{7}$ & $\begin{array}{l}\text { Severe headache after craniofa- } \\
\text { cial injury }\end{array}$ & $\begin{array}{l}\text { Clipping and wrapping of the } \\
\text { traumatic aneurysm, complete } \\
\text { recovery }\end{array}$ \\
\hline $\begin{array}{l}\text { DAVF draining into } \\
\text { the superficial } \\
\text { middle cerebral } \\
\text { vein } \\
1 \text { case }\end{array}$ & Ushikoshi et al, $2013^{30}$ & $\begin{array}{l}\text { Sudden onset of altered } \\
\text { consciousness }\end{array}$ & $\begin{array}{l}\text { Frontotemporal craniotomy, } \\
\text { clipping of the DAVF, complete } \\
\text { recovery }\end{array}$ \\
\hline $\begin{array}{l}\text { Metastasis of the } \\
\text { breast cancer } \\
1 \text { case }\end{array}$ & Pojskić et al (this case) & $\begin{array}{l}\text { Blurry and double vision on the } \\
\text { right side }\end{array}$ & $\begin{array}{l}\text { Orbitozygomatic pretemporal } \\
\text { craniotomy, extradural clinoi- } \\
\text { dectomy, complete recovery }\end{array}$ \\
\hline
\end{tabular}

Abbreviations: ACP, anterior clinoid process; DAVF, dural arteriovenous fistula; ICA, internal carotid artery.

carotid artery and ophthalmic aneurysms. ${ }^{34,35}$ It can be performed either intra- or extradural. Total clinoidectomy has been advocated in all neoplastic lesion of the clinoid, since at least a quarter of patients with radiographically negative imaging of ACP will have tumor involvement on pathological analysis. ${ }^{36}$

\section{Clinical Presentation}

Appropriate consent was obtained from the patient.

\section{Symptoms}

A 58-year-old male presented with headaches, right-sided blurred vision, and double vision. The cause of double vision was partial weakness of the right III nerve resulting from compression of the nerve by "hypertrophied" tumorinvolved right anterior clinoid. His previous medical history revealed existence of two primary malignant tumors: breast cancer (diagnosed 6 months prior) and prostate cancer (diagnosed 18 months prior). The patient was under treatment with chemotherapy due to breast cancer and showed no signs of active disease.

\section{Magnetic Resonance Imaging Presentation}

Postcontrast magnetic resonance imaging (MRI) of the head showed an extra-axial, well-bordered enhancing mass mea- suring $1.6 \times 1.1 \times 1.1 \mathrm{~cm}$ of the ACP with involvement of the right optic canal $(\mathrm{OC})$ along its superior lateral margin with dural tail typical for a meningioma. No other intracranial lesions were present. Meningioma was considered a primary differential diagnostic possibility preoperatively (-Fig. 1). The surgery was indicated due to symptomatic lesion, which progressively affected the vision on the right eye and to obtain the histological diagnosis.

\section{Surgical Technique}

Extradural clinoidectomy with tumor resection was performed by the senior author (K.I.A). The details of the orbitozygomatic pretemporal approach have been previously described. ${ }^{1,2,37-39}$ Skin incision and preparation of the temporalis muscle and orbitozygomatic craniotomy with drilling of the sphenoid ridge were performed in usual manner. ${ }^{37}$ The superior orbital fissure (SOF) was identified and unroofed, removing the bone overlying the superolateral margin of the SOF with rongeurs and a diamond burr. The meningo-orbital artery was coagulated and divided. Frontobasal and temporal dura were retracted with dural tack up sutures. Dura propria of the temporal lobe was peeled off from the SOF and the anteromedial aspect of the lateral wall of the cavernous sinus, exposing the third and the fourth cranial nerve as well as V1 and V2 of the fifth cranial nerve. Intraoperatively, the right III nerve was compressed by the hypertrophied 

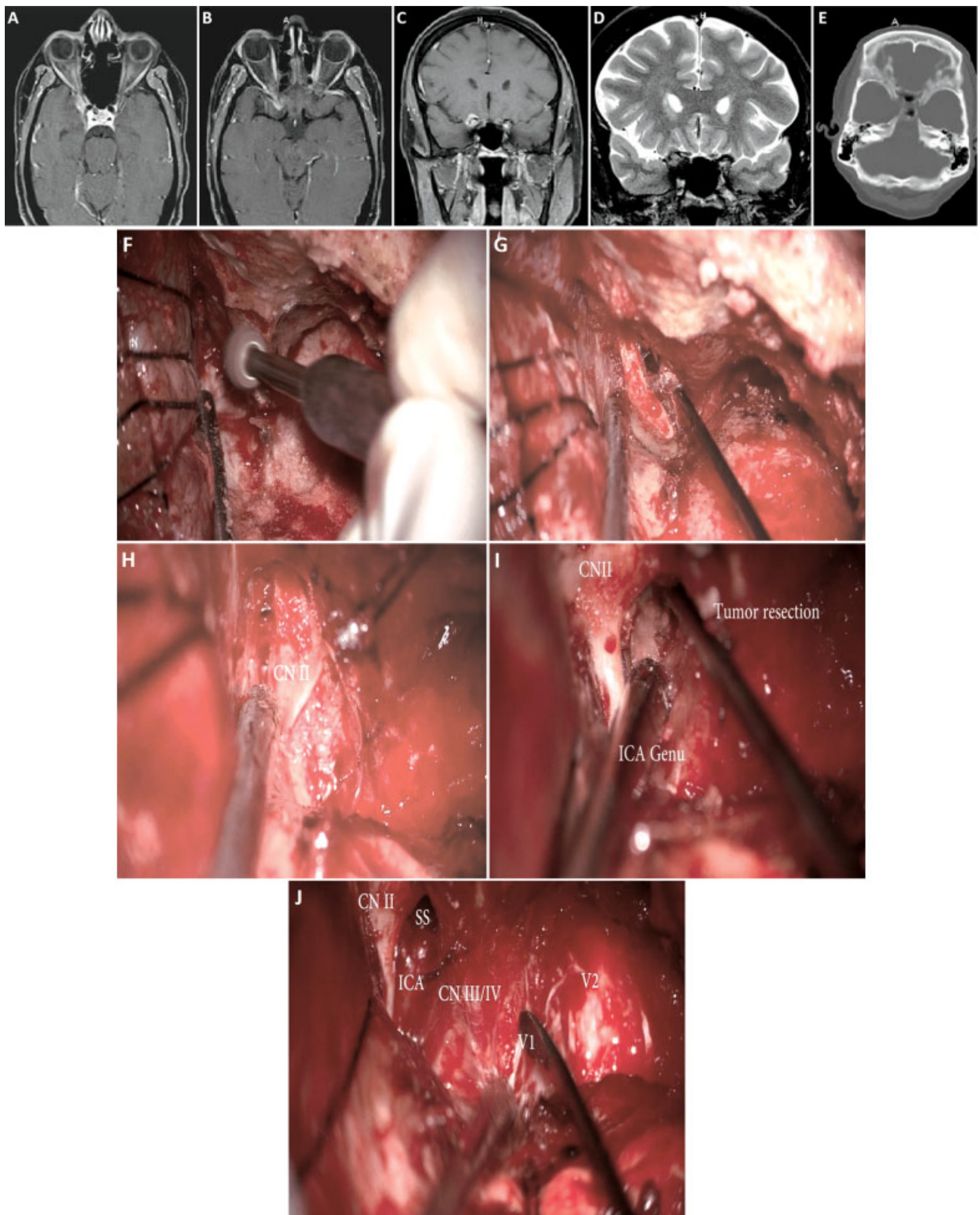

Fig. 1 Preoperative postcontrast magnetic resonance imaging (MRI) of the brain. (A) T1-weighted postcontrast axial view demonstrating a contrast-enhancing lesion on the right anterior clinoid process. (B) T1-weighted postcontrast axial view. (C) T1-weigted postcontrast coronal view, lesion on the right clinoid process resembling a clinoidal meningioma. (D) Preoperative T-2 weighted coronal MRI of the brain showing anterior clinoid involved by tumor adjacent to right optic nerve. (E) Computed tomography (CT) scan of the head, axial view. (F) Intraoperative microsurgical drilling of the right anterior clinoid. (G) Microsurgical dissection of the clinoid from periorbita. (H) Tumor inside the clinoid below the right optic nerve (labeled CN II). (I) Resection of the tumor extending into the right sphenoid sinus below the right optic nerve (CN II). Note also the right internal carotid artery (ICA) genu. (J) Microsurgical picture after resection of the tumor-involved right anterior clinoid. Please note the CN II optic nerve, ICA genu, III, IV, V1, and V2 nerves, and sphenoid sinus (SS) after removal of the tumor. 
tumor-involved anterior clinoid, but there was no evidence of dural or cavernous sinus tumor involvement.

The OC was then unroofed from a lateral to medial direction by using a 2-mm diamond burr with constantcooling irrigation. ${ }^{40}$ The tumor was involving the right anterior clinoid. The dorsal cortex of the clinoid was preserved and the tumor was involved in the central portion, penetrating ventrally and medially toward the sphenoid sinus. The opening of the sphenoid sinus was thusly done to ensure complete tumor resection and later obliterated with a small piece of muscle. Also, the third root of the ACP, the optic strut, was drilled off. During this procedure, constant awareness was maintained to protect the optic nerve, the carotid artery, and the oculomotor nerve with reference to the ACP. After removing the tumor that infiltrated the ACP, it was sent for histological analysis ( $\mathbf{- F i g . ~} \mathbf{1} \mathbf{f}-\mathbf{j}$ ).

\section{Pathohistology}

Pathohistological report showed the diagnosis of the metastasis of the known infiltrating ductal carcinoma of the breast (-Fig. 2).

\section{Follow-Up}

The postcontrast MRI showed no signs of the residual tumor (-Fig. 3). Blurred vision improved and double vision resolved completely. The patient continued to receive che- motherapy for infiltrating ductal carcinoma of the breast by his oncologist. Also, radiation treatment was initiated.

\section{Discussion}

A literature review of the past 30 years using the PubMed database did not display any results for metastasis of the clinoid process. The most common lesions of ACP are meningiomas. There were more than 20 studies that included patients with surgically treated meningiomas of the ACP. ${ }^{1,2,29,41-58}$ The second most common lesion of the ACP is mucocele. ${ }^{24}$-Table 1 provides the overview of isolated nonmeningioma lesions of the ACP reported so far in the literature.

\section{Magnetic Resonance Imaging Presentation}

Meningiomas demonstrate homogeneous enhancement on postcontrast MRI. ${ }^{59}$ Generally, there are several lesions that can mimic meningiomas, which usually present with pseudo-dural tail: breast cancer metastasis, ${ }^{60}$ cavernous hemangiomas, ${ }^{22,61}$ dural plasmocytoma, ${ }^{62,63}$ large capillary hemangioma, ${ }^{64}$ carcinoid tumor metastasis, ${ }^{65}$ pilocytic astrocytoma, ${ }^{16}$ liposarcoma, ${ }^{66}$ and metastatic thyroid carcinoma. ${ }^{67}$

\section{Breast Cancer and Brain Metastases}

Breast cancer represents the second most frequent cause of brain metastases, occurring in 10 to $16 \%$ of patients. ${ }^{68}$
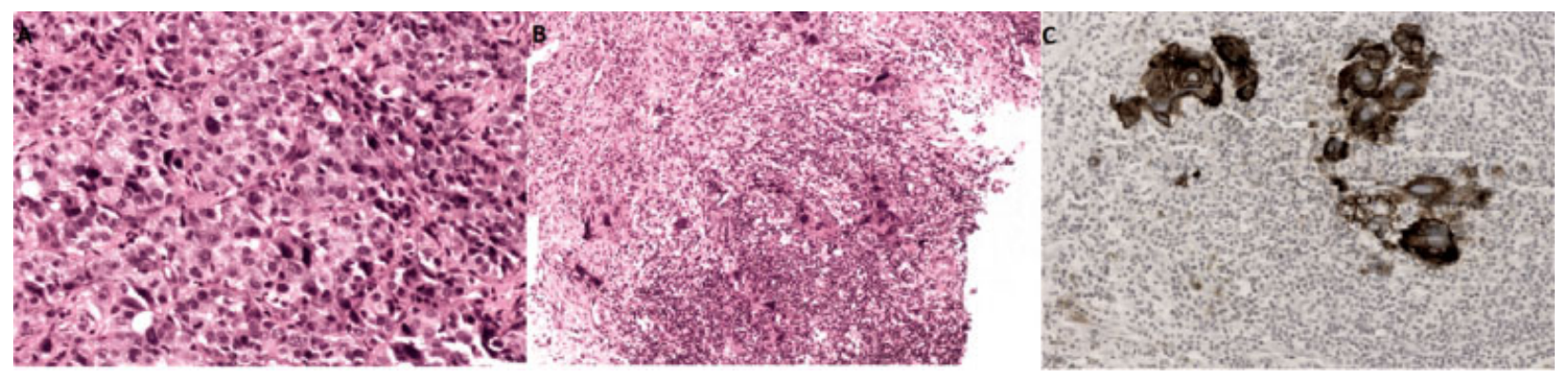

Fig. 2 Pathohistology specimens. (A) Tumor in the breast. Tumor consists of highly pleomorphic epithelial cells and corresponds to infiltrating ductal carcinoma of breast, poorly differentiated (Nottingham combined grade III). Hematoxylin and eosin (H\&E). Magnification $200 \times$. (B) Tumor in clinoid bone. Tumor consists of highly pleomorphic epithelial cells in desmoplastic stroma. H\&E. Magnification $100 \times$. (C) Tumor in clinoid bone. Tumor cells are strongly cytokeratin 7 positive. Cytokeratin 7 immunostaining. Magnification $200 \times$.
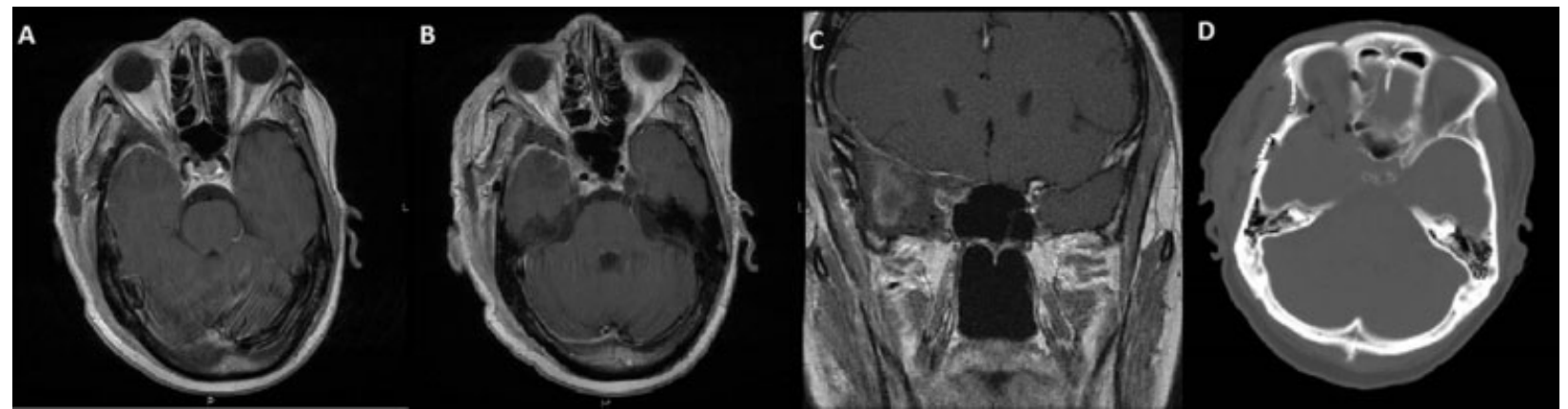

Fig. 3 Postoperative postcontrast magnetic resonance imaging (MRI) of the brain. (A) T1-weighted postcontrast axial view demonstrating a complete resection of the metastasis. (B) T1-weighted postcontrast axial view. (C) T1-weigted postcontrast coronal view, complete resection of the anterior clinoid. (D) Computed tomography (CT) scan of the head, axial view, demonstrating complete removal of the anterior clinoid process. 
Subgroups of patients with triple-negative and human epidermal growth factor receptor 2 (HER2)-positive breast cancer have an increased risk of developing brain metastases. ${ }^{69}$ Surgical resection of the brain metastasis is an important treatment option in patients with single or few ( $\leq 3$ ) lesions. ${ }^{70-72}$ However, the breast cancer metastasis or any other metastasis on the ACP has not been reported so far to our knowledge.

\section{Surgical Technique}

The extradural removal of the anterior clinoid process was initially described by Dolenc for vascular lesions of the cavernous sinus. ${ }^{73}$ Its use for pituitary adenomas, craniopharyngiomas, and clinoidal and tuberculum sellae meningiomas has been described. ${ }^{1,2}$ Approach can be pterional, ${ }^{74}$ orbitozygomatic, ${ }^{37,75}$ modified pterional, ${ }^{76}$ modified orbitozygomatic, ${ }^{40}$ pretemporal transzygomatic transcavernous, ${ }^{39,77}$ temporopolar epidural transcavernous transpetrous, ${ }^{78}$ extended lateral supraorbital, ${ }^{79}$ and endoscopic transsphenoidal. ${ }^{24}$

Extradural clinoidectomy has several advantages over intradural clinoidectomy. First, anatomical orientation is easily attained by identifying the dural extension into the SOF and the OC, and therefore a total ACP removal is possible. In contrast, when the intradural technique is used, both the extent of bone removal and the exposure that is gained may be limited. Second, the dura protects the intradural structures. Third, the procedure is performed during extradural exposure and also much faster than the intradural technique. ${ }^{76}$

With our first case report on the isolated metastasis of the anterior clinoid process, we provide an additional argument in favor of extradural clinoidectomy and in particular for malignant tumor pathology, since extradural resection minimizes the possibility of intradural tumor spread. Metastasis should now be included in the differential diagnosis of the lesions of the ACP. The possible spread of the metastatic disease intracranially in case of opening of the dura should be taken into consideration when planning a surgery.

\section{Conclusions}

This is the first case report of an ACP metastasis. It was treated successfully with extradural clinoidectomy. Metastasis should now be included in the differential diagnosis on the lesions of the anterior clinoid process. Extradural clinoidectomy is a safe and effective method in the treatment of these tumors, minimizing the risk of intradural tumor spread.

\section{Conflict of Interest}

No financial or material support was accepted as part of this study. None of the authors have any financial relationships to disclose.

\section{Acknowledgments}

The authors wish to thank Andrew J. Gienapp, BA (Department of Medical Education, Methodist University Hospital, Memphis, Tennessee, United States, and Department of Neurosurgery, University of Tennessee Health Science
Center, Memphis, Tennessee, United States), for copy editing, preparation of the manuscript, table, and figures for publishing, and publication assistance with this manuscript.

\section{References}

1 Al-Mefty O. Clinoidal meningiomas. J Neurosurg 1990;73(06): 840-849

2 al-Mefty O, Ayoubi S. Clinoidal meningiomas. Acta Neurochir Suppl (Wien) 1991;53:92-97

3 Aoyama Y, Ohtomo K, Sawamura H. Recurrent optic neuropathy caused by a mucocele of the anterior clinoid process after a 5-year remission: a case report and literature review. Neuroophthalmology 2014;38(05):281-285

4 Arnavielle S, Vignal-Clermont C, Galatoire O, et al. Compressive optic neuropathy related to an anterior clinoid mucocele [in French]. J Fr Ophtalmol 2010;33(03):208.e1-208.e6

5 Chagla AS, Bhaganagare A, Kansal R, Tyagi D. Complete recovery of visual loss following surgical treatment of mucopyocele of the anterior clinoid process. J Clin Neurosci 2010;17(05):670-672

6 Chang DJ. The "no-drill" technique of anterior clinoidectomy: a cranial base approach to the paraclinoid and parasellar region. Neurosurgery 2009;64(3, Suppl):ons96-ons105, discussion ons105ons106

7 Cheong JH, Kim JM, Kim CH. Bony protuberances on the anterior and posterior clinoid processes lead to traumatic internal carotid artery aneurysm following craniofacial injury. J Korean Neurosurg Soc 2011;49(01):49-52

8 Chou PI, Chang YS, Feldon SE, Chen JT. Optic canal mucocele from anterior clinoid pneumatisation. Br J Ophthalmol 1999;83(11): 1306-1307

9 Chung DS, Park YS, Lee JH, Kang JK. Mucocele of the anterior clinoid process: case report. Neurosurgery 1999;45(02):376-378

10 Deshmukh S, DeMonte F. Anterior clinoidal mucocele causing optic neuropathy: resolution with nonsurgical therapy. Case report. J Neurosurg 2007;106(06):1091-1093

11 Dunya IM, Frangieh GT, Heilman CB, Miranda MR, Rand LI, Hedges TR. Anterior clinoid mucocele masquerading as retrobulbar neuritis. Ophthal Plast Reconstr Surg 1996;12(03):171-173

12 Forer B, Hui NY, Sethi DS. Unilateral ophthalmoplegia secondary to anterior clinoid process mucocele. J Neuroophthalmol 2010;30 (04):321-324

13 Garaventa G, Arcuri T, Schiavoni S, Fonzari M. Anterior clinoid mucocele: a trans-nasal endoscopic approach. Minim Invasive Neurosurg 1997;40(04):144-147

14 Hejazi N, Witzmann A, Hassler W. Ocular manifestations of sphenoid mucoceles: clinical features and neurosurgical management of three cases and review of the literature. Surg Neurol 2001;56(05):338-343

15 Higgins HL, Schimdt JH III. Atypical presentation of a dermoid brain cyst. W V Med J 1996;92(06):312-315

16 Hong CS, Lehman NL, Sauvageau E. A pilocytic astrocytoma mimicking a clinoidal meningioma. Case Rep Radiol 2014; 2014:524574

17 Hopf-Jensen S, Rubarth O, von D Ahe I, et al. Isolated oculomotor nerve palsy caused by a mucocele of an aerated anterior clinoid process. Clin Neuroradiol 2014;24(02):161-164

18 Johnson LN, Hepler RS, Yee RD, Batzdorf U. Sphenoid sinus mucocele (anterior clinoid variant) mimicking diabetic ophthalmoplegia and retrobulbar neuritis. Am J Ophthalmol 1986;102 (01):111-115

19 Kasliwal MK, Suri A, Gupta DK, Suri V, Rishi A, Sharma BS. Sphenoid wing inflammatory pseudotumor mimicking a clinoidal meningioma: case report and review of the literature. Surg Neurol 2008;70(05):509-513, discussion 513

20 Kwon SH, Kim SH, Yoon JH. Anterior clinoid mucocele coexisting with sphenoid sinus mucocele. Auris Nasus Larynx 2009;36(05): 598-600 
21 Lim CC, Dillon WP, McDermott MW. Mucocele involving the anterior clinoid process: MR and CT findings. AJNR Am J Neuroradiol 1999;20(02):287-290

22 Mansour TR, Medhkour Y, Entezami P, Mrak R, Schroeder J, Medhkour A. The art of mimicry: anterior clinoid dural-based cavernous hemangioma mistaken for a meningioma. World Neurosurg 2017;100:708.e19-708.e22

23 Moisseiev E, Regenbogen M, Segev Y. Anterior clinoid process mucocele causing optic nerve compression [in Hebrew]. Harefuah 2013;152(02):76-78, 124

24 Nundkumar N, Mittal M, Kupsky WJ, Folbe A, Mittal S. Complete recovery of acute monocular visual loss following endoscopic resection of anterior clinoid mucocele: case report and review of the literature. J Neurol Sci 2012;312(1-2):184-190

25 O’Donnell TJ, Michael LM II, Laster R, Fleming JC. Isolated pyocele of anterior clinoid process presenting as a cavernous sinus syndrome. Tenn Med 2013;106(05):37-38, 43

26 Righini CA, Darouassi Y, Boubagra K, Schmerber S, Reyt E. Sphenoid sinus mucocele of unusual aetiology and location [in French]. Rev Laryngol Otol Rhinol (Bord) 2006;127(03):165-170

27 Schwaighofer BW, Sobel DF, Klein MV, Zyroff J, Hesselink JR. Mucocele of the anterior clinoid process: CT and MR findings. J Comput Assist Tomogr 1989;13(03):501-503

28 Thurtell MJ, Besser M, Halmagyi GM. Anterior clinoid mucocele causing acute monocular blindness. Clin Experiment Ophthalmol 2007;35(07):675-676

29 Tobias S, Kim CH, Kosmorsky G, Lee JH. Management of surgical clinoidal meningiomas. Neurosurg Focus 2003;14(06):e5

30 Ushikoshi S, Honma T, Uchida K, Yasuda H, Ajiki M. Dural arteriovenous fistula at the anterior clinoid process draining directly into the superficial middle cerebral vein. Neurol Med Chir (Tokyo) 2013;53(03):195-198

31 Vaphiades MS, Yunker JJ, Roberson GH, Meyer DR, Mills DM. Optic neuritis is nothing to sneeze at. Surv Ophthalmol 2007;52(01): 106-110

32 Wang AC, Than KD, Ramnath S, Pandey AS. Anterior clinoid mucocele presenting with orbital apex syndrome. Surg Neurol Int 2013;4:63

33 Yamashita T, Mikami T, Minamida Y, Baba T, Houkin K. Primary intraosseous cavernous hemangioma in anterior clinoid process [in Japanese]. No Shinkei Geka 2006;34(08):833-837

34 Drake CG, Vanderlinden RG, Amacher AL. Carotid-ophthalmic aneurysms. J Neurosurg 1968;29(01):24-31

35 Hauser MJ, Gass H. Optic nerve pressure by aneurysm relieved by decompression of optic nerve; report of a case. AMA Arch Opthalmol 1952;48(05):627-631

36 Copeland WR, Van Gompel JJ, Giannini C, Eckel LJ, Koeller KK, Link MJ. Can preoperative imaging predict tumor involvement of the anterior clinoid in clinoid region meningiomas? Neurosurgery 2015;77(04):525-529, discussion 530

37 Arnautović KI, Al-Mefty O, Angtuaco E. A combined microsurgical skull-base and endovascular approach to giant and large paraclinoid aneurysms. Surg Neurol 1998;50(06):504-518, discussion 518-520

38 Krisht AF. Transcavernous approach to diseases of the anterior upper third of the posterior fossa. Neurosurg Focus 2005;19(02):E2

39 Hsu SP, Krisht AF, Lin CF, et al. Immediate results of microsurgical clipping of posterior communicating artery aneurysms using the pretemporal transclinoidal approach. J Chin Med Assoc 2012;75 (09):454-458

40 Noguchi A, Balasingam V, Shiokawa Y, McMenomey SO, Delashaw JB Jr. Extradural anterior clinoidectomy. Technical note. J Neurosurg 2005;102(05):945-950

41 Tan Y, Xiao S, Zhang C, et al. Microsurgical resection of anterior clinoid meningiomas - 46 cases report [in Chinese]. Zhonghua Wai Ke Za Zhi 2014;52(04):271-275

42 Attia M, Umansky F, Paldor I, Dotan S, Shoshan Y, Spektor S. Giant anterior clinoidal meningiomas: surgical technique and outcomes. J Neurosurg 2012;117(04):654-665
43 Bassiouni H, Asgari S, Sandalcioglu IE, Seifert V, Stolke D, Marquardt G. Anterior clinoidal meningiomas: functional outcome after microsurgical resection in a consecutive series of 106 patients. Clinical article. J Neurosurg 2009;111(05):1078-1090

44 Pamir MN, Belirgen M, Ozduman K, Kiliç T, Ozek M. Anterior clinoidal meningiomas: analysis of 43 consecutive surgically treated cases. Acta Neurochir (Wien) 2008;150(07):625-635, discussion 635-636

45 Nanda A, Konar SK, Maiti TK, Bir SC, Guthikonda B. Stratification of predictive factors to assess resectability and surgical outcome in clinoidal meningioma. Clin Neurol Neurosurg 2016; 142:31-37

46 Tao CS, Lou MQ Lu YC, et al. Experience of resection large clinoidal meningiomas [in Chinese]. Zhonghua Wai Ke Za Zhi 2005;43(21): 1414-1417

47 Puzzilli F, Ruggeri A, Mastronardi L, Agrillo A, Ferrante L. Anterior clinoidal meningiomas: report of a series of 33 patients operated on through the pterional approach. Neuro-oncol 1999;1(03): 188-195

48 Goel A, Gupta S, Desai K. New grading system to predict resectability of anterior clinoid meningiomas. Neurol Med Chir (Tokyo) 2000;40(12):610-616, discussion 616-617

49 Risi P, Uske A, de Tribolet N. Meningiomas involving the anterior clinoid process. Br J Neurosurg 1994;8(03):295-305

50 Romani R, Laakso A, Kangasniemi M, Lehecka M, Hernesniemi J. Lateral supraorbital approach applied to anterior clinoidal meningiomas: experience with 73 consecutive patients. Neurosurgery 2011;68(06):1632-1647, discussion 1647

51 Sade B, Lee JH. High incidence of optic canal involvement in clinoidal meningiomas: rationale for aggressive skull base approach. Acta Neurochir (Wien) 2008;150(11):1127-1132, discussion 1132

52 Lee JH, Jeun SS, Evans J, Kosmorsky G. Surgical management of clinoidal meningiomas. Neurosurgery 2001;48(05):1012-1019, discussion 1019-1021

53 Cui H, Wang Y, Yin YH, Fei ZM, Luo QZ, Jiang JY. Surgical management of anterior clinoidal meningiomas: a 26-case report. Surg Neurol 2007;68(Suppl 2):S6-S10, discussion S10

54 Mariniello G, de Divitiis O, Seneca V, Maiuri F. Classical pterional compared to the extended skull base approach for the removal of clinoidal meningiomas. J Clin Neurosci 2012;19(12):1646-1650

55 Yang YM, Jiang HZ, Sha C, Yuan QG, Xie HW, Wang DM. Microsurgical management of anterior clinoidal meningiomas [in Chinese]. Zhonghua Yi Xue Za Zhi 2010;90(25):1764-1766

$56 \mathrm{Kim}$ JH, Jang WY, Jung TY, et al. Predictive factors for surgical outcome in anterior clinoidal meningiomas: analysis of 59 consecutive surgically treated cases. Medicine (Baltimore) 2017;96 (15):e6594

57 Chernov SV, Rzaev DA, Kalinovsky AV, et al. Early postoperative results of surgical treatment of patients with anterior clinoidal meningiomas [in Russian]. Vopr Neirokhir 2017;81(01):74-80

58 Czernicki T, Kunert P, Nowak A, Marchel A. Results of surgical treatment of anterior clinoidal meningiomas - our experiences. Neurol Neurochir Pol 2015;49(01):29-35

59 Watts J, Box G, Galvin A, Brotchie P, Trost N, Sutherland T. Magnetic resonance imaging of meningiomas: a pictorial review. Insights Imaging 2014;5(01):113-122

60 Altay T, Krisht KM, Couldwell WT. Sellar and parasellar metastatic tumors. Int J Surg Oncol 2012;2012:647256

61 Gupta RK, Saran RK, Jagetia A, Narang P. Extra-axial dural cavernous hemangioma with dural tail sign, masquerading as meningioma. J Neurosci Rural Pract 2016;7(04):615-616

62 Azarpira N, Noshadi P, Pakbaz S, Torabineghad S, Rakei M, Safai A. Dural plasmacytoma mimicking meningioma. Turk Neurosurg 2014;24(03):403-405

63 Morgenstern P, Pisapia D, Ramakrishna R. Calvarial plasmacytoma mimicking meningioma as the initial presentation of multiple myeloma. Cureus 2017;9(03):e1126 
64 Yang G, Li C, Chen X, et al. Large capillary hemangioma of the temporal bone with a dural tail sign: a case report. Oncol Lett 2014;8(01):183-186

65 Harrison CJ, Martin SC, Hofer M, Corkill R, Jeyaretna DS, Griffiths SJ. More than meets the MRI: case report of a carcinoid tumour metastasis mimicking a meningioma. Br J Neurosurg 2017:1-2. doi: 10.1080/02688697.2017.1327018

66 Zagzoog N, Ra G, Koziarz A, et al. Metastatic liposarcoma of the skull base: a case report and review of literature. Neurosurgery 2017;80(04):219-223

67 Malhotra G, Asopa RV, Sridhar E. Unusual case of isolated parasellar metastasis from carcinoma of thyroid. Clin Nucl Med 2013; 38(02):145-148

68 Lin NU, Bellon JR, Winer EP. CNS metastases in breast cancer. J Clin Oncol 2004;22(17):3608-3617

69 Gabos Z, Sinha R, Hanson J, et al. Prognostic significance of human epidermal growth factor receptor positivity for the development of brain metastasis after newly diagnosed breast cancer. J Clin Oncol 2006;24(36):5658-5663

70 Aversa C, Rossi V, Geuna E, et al. Metastatic breast cancer subtypes and central nervous system metastases. Breast 2014;23(05): 623-628

71 Leone JP, Lee AV, Brufsky AM. Prognostic factors and survival of patients with brain metastasis from breast cancer who underwent craniotomy. Cancer Med 2015;4(07):989-994
72 Leone JP, Leone BA. Breast cancer brain metastases: the last frontier. Exp Hematol Oncol 2015;4:33

73 Dolenc V. Direct microsurgical repair of intracavernous vascular lesions. J Neurosurg 1983;58(06):824-831

74 Dolenc VV. A combined epi- and subdural direct approach to carotid-ophthalmic artery aneurysms. J Neurosurg 1985;62(05): 667-672

75 Day JD, Giannotta SL, Fukushima T. Extradural temporopolar approach to lesions of the upper basilar artery and infrachiasmatic region. J Neurosurg 1994;81(02):230-235

76 Yonekawa Y, Ogata N, Imhof HG, et al. Selective extradural anterior clinoidectomy for supra- and parasellar processes. Technical note. J Neurosurg 1997;87(04):636-642

77 Krisht AF, Kadri PA. Surgical clipping of complex basilar apex aneurysms: a strategy for successful outcome using the pretemporal transzygomatic transcavernous approach. Neurosurgery 2005;56(2, Suppl):261-273, discussion 261-273

78 Roche PH, Mercier P, Fournier HD. Temporopolar epidural transcavernous transpetrous approach. Technique and indications [in French]. Neurochirurgie 2007;53(01):23-31

79 Andrade-Barazarte $\mathrm{H}$, Jägersberg $\mathrm{M}$, Belkhair $\mathrm{S}$, et al. The extended lateral supraorbital approach and extradural anterior clinoidectomy through a frontopterio-orbital window: technical note and pilot surgical series. World Neurosurg 2017; 100:159-166 